\title{
Do Expectations Play Any Role in Determining Pak Rupee Exchange Rates?
}

\author{
RAZZAQUE H. BHATTI
}

\begin{abstract}
This paper presents some evidence on the role of expectations in the determination of Pak rupee exchange rates vis-à-vis the dollar, pound, and yen over the period 1982:11993:7. Results of cointegration and coefficient restriction tests in two out of three cases are supportive of the view of exchange rate determination in postulating that in efficient markets in which uncertainty and expectations about the future are dominant, the equilibrium nominal exchange rate is determined not only by current relative prices but also by the expected real exchange rate. These results are supportive of ex ante purchasing power parity, implying that the real exchange rate follows a random walk. These results also suggest that the anticipated inflation rate is higher in Pakistan than in other countries, which tends to encourage the domestic residents to convert their current balances into foreign currency, so that the terms of trade deteriorate and offset much of gains of the continuous devaluation of Pak rupee by undermining external competitiveness.
\end{abstract}

\section{INTRODUCTION}

Since the advent of floating exchange rates by major industrial countries in 1973, there has been an increased interest in analysing the process of exchange rate determination. As the earliest formal explanation of exchange rate determination, the purchasing power parity (PPP) theory has emerged as a natural starting-point from which to investigate economic fundamentals underlying the process of exchange rate behaviour. ${ }^{1}$ The PPP theory, which was originally put forward by Cassel (1916), postulates that under a system of floating exchange rates, so long as trade is free and transportation costs, capital flows, and speculative expectations are absent, the nominal exchange rate between two national currencies tends to be essentially in line with the ratio of the domestic price level to the foreign price level, and the real exchange rate to be the mean reverting over time.

However, most studies dealing with the empirical testing of PPP have documented evidence that usually indicates the failure of the theory. ${ }^{2}$ One reason for the failure of PPP, as suggested by Roll (1979) and Adler and Lehman (1983), is that

Razzaque H. Bhatti is Associate Professor of Economics at the International Institute of Islamic Economics, International Islamic University, Islamabad.

${ }^{1}$ While PPP may be considered as a theory of inflation under fixed exchange rates, it is just an equilibrium condition under flexible exchange rates. Under fixed exchange rates, PPP implies that inflation rates, subject to certain reservations, must be equal in all countries of an integrated world economy [see, for example, Genberg (1978)].

${ }^{2}$ See, inter alia, Frenkel (1981); Taylor (1988); Patel (1990); Nachane and Chrissanthaki (1991); Crowder (1992); Flynn and Boucher (1993); Cooper (1994); Serletis (1994) and Moosa and Bhatti (1996). For a detailed and comprehensive survey of PPP, see also Moosa and Bhatti (1997a). 
efficient markets competition among speculators tends to establish PPP on ex ante basis, so that expected changes in the real exchange rate are serially uncorrelated over time, indicating that the real exchange rate follows a random walk. This implies that there is no theoretical reason for the real exchange rate to reach some constant value. Therefore, results supportive of ex ante PPP can be interpreted as implying the reason why conventional PPP fails to perform well empirically. Bhatti and Moosa (1994) view the failure of conventional PPP in a different perspective. They argue that conventional PPP fails to perform well over the current flexible exchange rate regime because it neglects the role of uncertainty and expectations in exchange rate determination. Based on ex ante PPP, they put forward a new view of exchange rate determination which postulates that in efficient markets in which there is presence of uncertainty and expectations about the future, the exchange rate is determined not only by current relative prices but also by the expected real exchange rate. ${ }^{3}$

The objective of this paper ${ }^{4}$ is to test the validity of this view of exchange rate determination for three Pak rupee exchange rates vis-à-vis the dollar, pound, and yen over the period 1982:1-1993:7. ${ }^{5}$ The testing technique will be cointegration analysis because it provides an especially suitable framework for evaluating long-run relationships while allowing for short-run deviations. Cointegration analysis is superior to conventional regression analysis for at least two reasons. First, it produces superconsistent estimates of the regression parameters, despite the presence of such problems as simultaneity, serial correlation, and heteroscedasticity [Stock (1987)]. Second, making inferences about the numerical values of the estimated coefficients of the non-stationary regressors on the basis of the conventional standard errors and $t$-statistics is erroneous because they do not have limiting normal distribution [Engle and Granger (1991)]. However, in cointegration analysis the $t$ statistics calculated from the OLS standard errors can be corrected along the lines suggested by West (1988) in order to give them a limiting normal distribution.

${ }^{3}$ In fact, uncertainty about future prices is a central feature of the efficient markets paradigm [see Roll (1979), p. 137].

${ }^{4}$ An earlier version of this paper was presented at the National Conference on Business Administration and Economics, held at IBA, Karachi, May 20-22, 1996.

${ }^{5}$ One reason for picking out Pak rupee exchange rates for this period is that the authorities have never been formally committed to defending a specific exchange rate since they opted for a managed float in April 1982: instead, they allowed the exchange rate to move to its new equilibrium value when they wanted it to change and entered the market to keep the rate constant when they did not. This does not follow that one cannot test both forms of PPP for fixed exchange rates. It is important, however, to determine the direction of normalisation while testing the former hypothesis for fixed and flexible exchange rates. Researchers usually normalise the conventional PPP model on nominal exchange rates if exchange rates are flexible, and on domestic prices if exchange rates are fixed. The significance of choosing different directions of normalisation is that PPP can be used as an explanation of the transmission mechanism of world inflation and movements in exchange rates [see, for example, Moosa and Bhatti (1997a), pp. 202-204]. As for the ex ante PPP hypothesis, it can be tested both for flexible and fixed exchange rates. However, empirical results may produce more pronounced rejections of the hypothesis in the latter case than in the former [see Adler and Lehman (1983), p. 1477]. 


\section{THE ROLE OF EXPECTATIONS}

An important assumption underlying ex ante PPP is that market agents are uncertain about future movements in prices and exchange rates and, as a result, they are more concerned with the expected (than with the current) purchasing power of their return on investment, domestic and foreign. For example, if the future inflation rate is expected to be higher at home than abroad, domestic market agents will find it worthwhile to convert their current balances into foreign currency in anticipation of gains from depreciation (appreciation) of the domestic (foreign) currency. Therefore, if the nominal exchange rate moves to equalise the expected domestic and foreign inflation rates, then the equilibrium nominal exchange rate is not only determined by current relative prices but also by the expected real exchange rate. This implies that the country with relatively high expected inflation rate will have an undervalued currency based on current purchasing power, while the country with relatively low expected inflation rate will have an overvalued currency. Consequently, the terms of trade will improve for the latter and deteriorate for the former. Moreover, this implies that while devaluation improves external competitiveness, the larger expected inflation rate at home (than that abroad) will eventually offset much of its gains by undermining external competitiveness.

Ex ante PPP postulates that the expected rate of change in the nominal exchange rate tends to be exactly equal to the expected differential in inflation rates across countries over the same holding period. This relationship is given by

$$
\Delta s_{t+1}^{e}=\Delta p_{t+1}^{e}-\Delta p_{t+1}^{* e} \quad \ldots \quad \ldots \quad \ldots \quad \ldots \quad \ldots
$$

where $\Delta$ is the difference operator, $s_{t}$ is (the logarithm of) the nominal exchange rate (defined as the domestic currency price of one unit of the foreign currency), $p_{t}\left(p_{t}^{*}\right)$ is (the logarithm of) the domestic (foreign) price level, and the superscript $e$ indicates the value of the variable expected at time $t$ to prevail at time $t+1$.

Equation (1) may be derived by assuming either efficiency in international financial markets or efficiency in international commodity markets. Efficiency in international commodity markets obtains when the expected return to speculators engaged in intertemporal speculation on commodities (i.e., buying a domestic commodity today and selling it abroad tomorrow) is equal to zero. An implicit assumption underlying conventional PPP is that market agents are certain about the future and compete with each other on arbitrage profit opportunities arising out of differences between the domestic prices and the exchange-rate-adjusted foreign prices of goods. This arbitrage condition boils down to the PPP equation which can be written as

$$
\begin{array}{lllllll}
s_{t}=p_{t}-p_{t}^{*} & \ldots & \ldots & \ldots & \ldots & \ldots & \ldots
\end{array}
$$


If transportation costs and trade barriers are absent, Equation (2) implies that deviations from parity indicate the existence of profitable opportunities for commodity arbitrage. Deviations from PPP imply that the same good, after adjusting for the exchange rate, will sell at different prices between home and abroad. Simultaneously buying the good in the low-price country and selling the good in the high-price country will force the nominal exchange rate to PPP and the real exchange rate to some constant value. Therefore, conventional PPP requires the return to speculators engaged in temporal speculation on goods, buying goods at home at the domestic price, $p_{t}$, and selling them abroad at the exchange-rate-adjusted foreign price, $s_{t}+p_{t}^{*}$, to be equal to zero.

In empirically testable form, conventional PPP can be written as follows

$$
s_{t}=\alpha_{0}+\alpha_{1}\left(p-p^{*}\right)_{t}+u_{t} \quad \ldots \quad \ldots \quad \ldots \quad \ldots \quad \ldots
$$

Clearly ex ante PPP differs from conventional PPP because market agents are assumed to be uncertain about future movements in prices and exchange rates, and because they form expectations about future exchange rates and prices. Therefore, unlike the conventional PPP market, agents in ex ante PPP are assumed to lose out on arbitrage profit opportunities arising out of the differences not only between the current but also between the expected prices of domestic and foreign goods. In other words, ex ante PPP requires that not only the return to speculators engaged in temporal speculation on goods but also the return to speculators engaged in intertemporal speculation on goods be equal to zero. Suppose, if transaction costs are absent, then the return to speculators engaged in temporal speculation on goods is given by

$$
\begin{array}{llllll}
\pi_{t}=s_{t}+p_{t}^{*}-p_{t} & \ldots & \ldots & \ldots & \ldots & \ldots
\end{array}
$$

where $\pi_{t}$ (representing the real exchange rate) is the profit which is made by speculator by buying goods at home and selling them abroad. On the other hand, the profit made by speculators in intertemporal speculation on goods is given by

$$
\pi_{t+1}^{e}=s_{t+1}^{e}+p_{t+1}^{* e}-p_{t+1}^{e} \quad \ldots \quad \ldots \quad \ldots \quad \ldots \quad \ldots
$$

where $\pi_{t+1}^{e}$ also represents the expected real exchange rate. Thus, the net return from temporal and intertemporal speculation on goods is given by

$$
\pi_{t+1}^{e}-\pi_{t}=\Delta s_{t+1}^{e}+\Delta p_{t+1}^{* e}-\Delta p_{t+1}^{e} \quad \ldots \quad \ldots \quad \ldots \quad \ldots
$$


If markets are efficient in Fama's (1970) sense, then today prices must reflect all information available to agents, so that current prices are the best forecast of future prices. Therefore, $\pi_{t+1}^{e}-\pi_{t}=\omega_{t}$ where the error term, $\omega_{t}$, is completely random, displaying no pattern over time, Equation (5) reduces to Equation (1), which can be rewritten in level form as

$$
s_{t}=\left(p_{t}-p_{t}^{*}\right)+\left(s_{t+1}^{e}-p_{t+1}^{e}+p_{t+1}^{* e}\right) \quad \ldots \quad \ldots \quad \ldots
$$

This implies that the nominal exchange rate is not only determined by current relative prices but also by the expected real exchange rate, implying also that the omission of the latter makes the conventional PPP model misspecified.

Equation (6) can be rewritten in an empirically testable form as

$$
s_{t}=\beta_{0}+\beta_{1}\left(p-p^{*}\right)+\beta_{2} q_{t+1}^{e}+u_{t} \quad \ldots \quad \ldots \quad \ldots \quad \ldots
$$

where $q_{t+1}^{e}$ is the expected real exchange rate (defined as $q_{t+1}^{e}=s_{t+1}^{e}-p_{t+1}^{e}+p_{t+1}^{* e}$ ). If expectations play any role in determining the exchange rate, than $\beta_{2}$ should be significantly different from zero. Moreover, the restrictions $\beta_{0}=0, \beta_{1}=1$ and $\beta_{2}=1$ can also be tested to examine if the nominal exchange rate moves in one-to-one correspondence with the relative price and expected real exchange rate.

It is worth noting that Equation (7) cannot be tested empirically unless the expected real exchange rate is quantified. For this purpose, let us assume that market agents across countries are able to form expectations rationally, such that the actual (ex post) real exchange rate realised at time $t+1$ differs from the expected real exchange rate by a random error which is orthogonal to the past real exchange rate. Therefore,

$$
\begin{array}{llllll}
q_{t+1}=q_{t+1}^{e}+v_{t+1} & \ldots & \ldots & \ldots & \ldots & \ldots
\end{array}
$$

where $v_{t+1}$ is a zero-mean serially uncorrelated real exchange rate forecasting error.

By substituting Equation (7) into Equation (8), we obtain

$$
s_{t}=\beta_{0}+\beta_{1}\left(p-p^{*}\right)_{t}+\beta_{2} q_{t+1}+\varepsilon_{t} \quad \ldots \quad \ldots \quad \ldots \quad \ldots
$$

where $\varepsilon_{t}=u_{t}-\beta_{2} v_{t+1}$. Equation (9) forms the basis of testing ex ante PPP [see Bhatti and Moosa (1994)]. ${ }^{6}$

\footnotetext{
${ }^{6}$ Ex ante PPP can also be tested using other model specifications. For a brief summary of these alternative approaches to testing ex ante PPP, see Bhatti and Moosa (1994), p. 149.
} 


\section{EMPIRICAL RESULTS}

Testing the proposition as to whether or not expectations play any role in the determination of exchange rate is carried out by estimating Equation (9). For this purpose, monthly data were collected on three exchange rates-rupee-dollar, rupeepound, and rupee-yen-and on wholesale prices over the period 1982:1-1993:7. All data were obtained from Datastream (IMF series).

Before testing for cointegration, unit root tests are carried out to examine if the variables underlying Equation (9) are integrated of the same order. Testing for unit root in levels and first differences of the variables $s_{t},\left(p-p^{*}\right)_{t}$ and $q_{t+1}$ is conducted on the basis of three tests statistics: the Dickey-Fuller (1979) $\tau_{\mu}$ statistics and the Phillips-Ouliaris (1990) $\hat{Z}_{a}$ and $\hat{Z}_{t}$ statistics. The results obtained from the three unit-root test statistics, as shown in Table 1, are consistent in indicating that all the variables underlying Equation (9) are non-stationary in levels and stationary in first differences, implying that they are $I(1){ }^{7}$

Table 1

Testing for Unit Root

\begin{tabular}{|c|c|c|c|c|c|c|c|}
\hline \multirow[b]{2}{*}{ Country } & \multirow[b]{2}{*}{ Variable } & \multicolumn{3}{|c|}{ Level } & \multicolumn{3}{|c|}{ First Difference } \\
\hline & & $\tau_{\mu}$ & $\hat{Z}_{a}$ & $\hat{Z}_{t}$ & $\tau_{\mu}$ & $\hat{Z}_{a}$ & $\hat{Z}_{t}$ \\
\hline \multirow[t]{3}{*}{ Pak-U.S. } & $s_{t}$ & -0.877 & -0.720 & -0.843 & $-7.626^{*}$ & $-98.27^{*}$ & $-7.109 *$ \\
\hline & $q_{t+1}$ & -2.171 & -8.977 & -2.328 & $-9.378 *$ & $-11.06^{*}$ & $-9.018 *$ \\
\hline & $\left(p-p^{*}\right)_{t}$ & 0.230 & 0.285 & 0.625 & $-8.797 *$ & $-74.02^{*}$ & $-9.641^{*}$ \\
\hline \multirow[t]{3}{*}{ Pak-Japan } & $s_{t}$ & 0.074 & -0.024 & -0.029 & $-10.957^{*}$ & $-150.97 *$ & $-11.208^{*}$ \\
\hline & $q_{t+1}$ & 0.619 & -0.889 & -0.536 & $-11.766 *$ & $-134.88 *$ & $-11.854^{*}$ \\
\hline & $\left(p-p^{*}\right)_{t}$ & 0.775 & 0.231 & 0.562 & $-9.937 *$ & $-114.73 *$ & $-9.771^{*}$ \\
\hline \multirow[t]{3}{*}{ Pak-U.K. } & $s_{t}$ & -0.495 & -0.526 & -0.430 & $-10.708 *$ & $-108.58 *$ & $-10.754^{*}$ \\
\hline & $q_{t+1}$ & -1.010 & -1.736 & -0.968 & $-10.572 *$ & $-105.00 *$ & $-10.583^{*}$ \\
\hline & $\left(p-p^{*}\right)_{t}$ & 0.726 & 1.135 & 1.272 & $-5.573 *$ & $-66.21 *$ & $-8.312^{*}$ \\
\hline
\end{tabular}

*Significant at the 5 percent level.

Testing for cointegration is conducted on the basis of the Engle-Granger (1987) and the Phillips-Ouliaris (1990) procedures. Two test statistics are used in conjunction with each cointegration test: while $A D F$ and $C R D W$ statistics are used with the Engle-Granger test, $\hat{Z}_{a}$ and $\hat{Z}_{t}$ statistics are used with the Phillips-Ouliaris test. Results of cointegration and coefficient restrictions tests are reported in Table 2. The results from four cointegration test statistics, $C R D W, A D F, \hat{Z}_{a}$ and $\hat{Z}_{t}$, are

${ }^{7}$ Today there is ample evidence showing that most of the macroeconomic time series are nonstationary, including the ratio of the domestic price index to the foreign price index. The unit-root results of this study are perfectly compatible with those of bulk of studies carried out, inter alia, by Taylor (1988); Patel (1990); Flynn and Boucher (1993); Cooper (1994); Bhatti and Moosa (1994) and Moosa and Bhatti (1997). 
Table 2

\begin{tabular}{lccc}
\multicolumn{4}{c}{ Testing for Cointegration $\left(\mathrm{s}_{\mathrm{t}}=\beta_{0}+\beta_{1}\left(\mathrm{p}-\mathrm{p}^{*}\right)_{\mathrm{t}}+\beta_{2} \mathrm{q}_{\mathrm{t}+1}+\varepsilon_{\mathrm{t}}\right)$} \\
\hline$\beta_{0}$ & Pak-U.S. & Pak-Japan & Pak-U.K. \\
$\beta_{1}$ & 0.099 & -0.198 & 0.177 \\
& $(0.102)$ & $(0.101)$ & $(0.062)$ \\
$\beta_{2}$ & 1.012 & 1.045 & 1.130 \\
& $(0.012)$ & $(0.027)$ & $(0.045)$ \\
$R^{2}$ & 0.962 & 0.927 & 0.941 \\
$C R D W$ & $(0.038)$ & $(0.038)$ & $(0.020)$ \\
$A D F$ & 0.995 & 0.996 & 0.987 \\
$\hat{Z}_{a}$ & $1.426^{*}$ & $1.797^{*}$ & $1.797^{*}$ \\
$\hat{Z}_{t}$ & $-8.920^{*}$ & $-10.521^{*}$ & $-10.521^{*}$ \\
$t^{*}\left(\beta_{0}=0\right)$ & $-103.65^{*}$ & $-104.035^{*}$ & $-104.487^{*}$ \\
$t^{*}\left(\beta_{1}=1\right)$ & $-8.51^{*}$ & $-10.487^{*}$ & $-10.487^{*}$ \\
$t^{*}\left(\beta_{2}=0\right)$ & 0.971 & 1.96 & $2.85^{*}$ \\
$t^{*}\left(\beta_{2}=1\right)$ & 1.00 & 1.67 & $2.89^{*}$ \\
\hline
\end{tabular}

* Significant at the 5 percent level. The West-corrected standard errors are reported in parentheses. $t^{*}$ is the corrected $t$-statistic which is calculated on the basis of the corrected standard errors.

highly consistent in lending support to the role of expectations in determining Pak rupee exchange rates because the coefficient on the expected real exchange rate is highly significant in all cases. However, the results are not supportive of the hypothesis that the nominal exchange rate moves in one-to-one correspondence with the relative price, and expected real exchange rate in all cases. Only in two cases (rupee-dollar and rupee-yen) are the restrictions $\beta_{0}=0, \beta_{1}=1, \beta_{2}=1$ accepted as judged by the West (1988) corrected $t$-statistic. These results lend strong support to ex ante PPP predicting that the real exchange rate follows a random walk, and also to the view postulating that the nominal exchange is determined not only by current relative prices but also by the expected real exchange rate. Moreover, these results are highly consistent with those obtained by Bhatti and Moosa (1994), who tested the validity of this view for ten major industrial countries and found favourable results in almost all cases.

These results may not, however, be interpreted as implying that the authorities in Pakistan have been able to choose nominal values of Pak rupee exchange rates in line with their economic fundamentals, and that there has been no misalignments of Pak rupee real exchange rates over the period under investigation. This is because Pak rupee real exchange rates have not been seen to be reverting to their long-run (PPP) values over time, and hence have become unstable, indicating the presence of 
substantial and prolonged deviations from conventional PPP which are often interpreted as causing misalignments of real exchange rates. ${ }^{8}$ This evidence, of course, is not sufficient to support if Pak rupee real exchanges have been moving in line with their economic fundamentals. This has been done more formally and rigorously by Haque and Montiel (1992); Chishti and Hasan (1993); Afridi (1995); and Siddiqui et al. (1996), who conducted empirical tests to explore economic fundamentals determining Pak rupee real exchange rate or Pak rupee real effective exchange rate. Most of these studies define and model Pak rupee real exchange rate on the lines followed by Edwards (1989), who examined determinants as well as misalignments of real exchange rates. ${ }^{9}$ These studies modelled Pak rupee real exchange rate by explicitly postulating that the real exchange rate is endogenously determined by two broad sets of economic fundamentals: internal as well as external economic fundamentals. ${ }^{10}$ Haque and Montiel (1992) investigated Pakistan's experience of managed floating exchange rate policy over the period 1982-1991, as well as future challenges in this regard. To support their views about the behaviour of Pak rupee exchange rate, they conducted some empirical tests to identify economic fundamentals accounting for systematic movements in Pak rupee real

${ }^{8}$ [Pilbeam (1992), pp. 270-273.]

${ }^{9}$ Researchers have usually used numerous and often contradictory definitions of the real exchange rate [see Edwards (1988), pp. 47-48]. Unlike the earliest view based on PPP, which defines the real exchange rate as the nominal exchange rate adjusted by the ratio of the domestic to the foreign price index, the other definitions view the real exchange rate as the relative price of tradables to non-tradables. It is interesting to note that in the former case the real exchange rate is also determined by the ratio of the prices of tradables to non-tradables. Assuming that PPP holds for tradables only, the nominal exchange rate can be hypothesised to depend on both the relative price and the relative price structure, such that the former is determined by monetary factors while the latter is determined by real factors. Therefore, the PPP relationship is given by

$$
s_{t}=\left(p-p^{*}\right)_{t}+\left[\left(p_{T}-p_{N}\right)_{t}-\left(p_{T}^{*}-p_{N}^{*}\right)_{t}\right]
$$

where $\left[\left(p_{T}-p_{T}\right)-\left(p_{T}^{*}-p_{N}^{*}\right)\right]$ is the relative price structure determined by the ratio of the prices of tradables to non-tradables across countries. This equation implies that if monetary conditions are similar, the nominal exchange rate will be determined by structural changes, while if the internal price structure across countries remains stable, the exchange rate will be determined by relative prices as represented by Equation (2). Thus, Equation (2) holds only if shocks are mainly of monetary origin. In contrast, if shocks are not mainly of monetary origin, and the relative price structure is not stable over time, then the omission of the term $\left[\left(p_{T}-p_{T}\right)-\left(p_{T}^{*}-p_{N}^{*}\right)\right]$, which represents structural changes, makes the PPP model misspecified. This is known as Balassa's (1964) productivity bias hypothesis, which can be tested by regressing the real exchange rate on productivity differences across countries [see Bahmani-Oskooee (1992)]. This model can be further extended to incorporate both domestic and external variables to examine the behaviour of the real exchange rate.

${ }^{10}$ It is worth noting that while the equilibrium real exchange rate is determined by real variables only, the actual real exchange rate may respond both to real and monetary variables [see, for example, Edwards (1988), p. 9]. Consequently, the actual real exchange rate may deviate from its long-run equilibrium value, and if these deviations are substantial and persistent, they will cause misalignments of the real exchange rate. 
exchange rate. Regressing the log value of the real effective exchange rate on the log values of Pakistan's external terms of trade, the ratio of remittance receipts plus official transfers to GNP, they obtained results showing that the workers' remittances and official reserves, which have in fact provided the bulk of Pakistan's external receipts over the period under study, significantly explain the behaviour of Pak rupee real effective exchange rate. These results were interpreted as implying that the authorities have been successful in tracking, through nominal exchange rate policy, the underlying trend in the equilibrium real effective exchange rate over the period under investigation.

Siddiqui et al. (1996) applied a simultaneous equation system to model the behaviour of Pak rupee real exchange rate over the period 1960-94. Employing the two-stage least square procedure, they produced results indicating that almost all variables, including, inter alia, excess domestic credit, net capital flows (defined as the sum of net foreign borrowing, foreign aid, and net income from abroad), and technological change, turned out to be factors significantly affecting the behaviour of Pak rupee real exchange rate. However, the results showed also that terms of trade did not effect the real exchange rate significantly, an evidence which is supportive of earlier findings obtained by Haque and Montiel (1992) and Afridi (1995). Based on these results, Siddiqui et al. (1996) suggested controlling both monetary and real variables together with domestic prices, instead of repeated devaluations, to maintain stability in Pak rupee real exchange rate.

\section{CONCLUSION}

This paper has tested the proposition as to whether or not expectations play any role in determining three Pak rupee exchange rates: rupee-dollar, rupee-pound, and rupee-yen. Results from two residual-based cointegration tests are in line with the view that in efficient markets in which uncertainty and expectations about the future are present, the nominal exchange rate is determined not only by current relative prices but also by the expected real exchange rate. These results lend support to ex ante PPP as against conventional PPP.

The policy implications that can be drawn from these results are as follows. First, the inflation rate is expected to be higher in Pakistan than in other countries, which in turn is likely to cause depreciation of Pak rupee. Second, the anticipated depreciation of Pak rupee is expected to encourage the domestic residents to transfer their assets into foreign assets, leading to the flight of capital from Pakistan. Third, terms of trade for Pakistan also tend to deteriorate because of a higher anticipated inflation rate at home than that abroad. Finally, the tendency to a larger expected inflation rate in Pakistan eventually offsets much of the gains from a continuous devaluation of Pak rupee by undermining external competitiveness. 


\section{REFERENCES}

Adler, M., and B. Lehman (1983) Deviations from Purchasing Power Parity in the Long Run. Journal of Finance 38: 1471-1487.

Afridi, U. (1995) Determining Real Exchange Rates. The Pakistan Development Review 34:3 263-276.

Bahmani-Uskooee, M. (1992) A Time Series Approach to the Productivity Bias Hypothesis in Purchasing Power Parity. Kyklos 45: 227-36.

Balassa, B. (1964) The Purchasing Power Parity Doctrine: A Reappraisal. Journal of Political Economy 72: 584-596.

Bhatti, R. H., and I. A. Moosa (1994) A New Approach to Testing Ex Ante Purchasing Power Parity. Applied Economics Letters 1: 148-151.

Cassel, G. (1916) The Present Situation of the Foreign Exchange. Economic Journal 26: 62-65.

Chishti, S., and M. A. Hasan (1993) What Determines the Behaviour of Real Exchange Rate in Pakistan? The Pakistan Development Review 32:4 10151028.

Cooper, J. C. B. (1994) Purchasing Power Parity: A Cointegration Analysis of the Australian, New Zealand, and Singaporean Currencies. Applied Economics Letters 1: 167-171.

Crowder, W. J. (1992) Purchasing Power Parity over the Modern Float: An Application in Higher Order Cointegration. Economics Letters 40: 313-318.

Dickey, D. A., and W. A. Fuller (1979) Distribution of the Estimators for Autoregressive Time Series with a Unit Root. Journal of the American Statistical Association 74: 427-431.

Edwards, S. (1988) Exchange Rate Misalignment in Developing Countries. Baltimore and London: The Johns Hopkins University Press.

Edwards, S. (1989) Real Exchange Rates, Devaluation, and Adjustment: Exchange Rate Policy in Developing Countries. Cambridge, Massachusetts: The MIT Press.

Engle, R. F., and C. W. J. Granger (1987) Cointegration and Error Correction: Representation, Estimation, and Testing. Econometrica 55: 251-276.

Engle, R. F., and C. W. J. Granger (eds) (1991) Long-run Economic Relationships: Readings in Cointegration. Oxford: Oxford University Press.

Fama, E. F. (1970) Efficient Capital Markets: A Review of Theory and Empirical Work. Journal of Finance 25: 383-417.

Flynn, N. A., and J. L. Boucher (1993) Tests of Long-run Purchasing Power Parity Using Alternative Methodologies. Journal of Macroeconomics 15: 109-122.

Frenkel, J. A. (1981) The Collapse of Purchasing Power Parities during the 1970s. European Economic Review 16: 145-165.

Genberg, H. (1978) Purchasing Power Parity under Fixed and Flexible Exchange Rates. Journal of International Economics 8: 247-270. 
Haque, N. Ul., and P. J. Montiel (1992) Exchange Rate Policy in Pakistan: Recent Experience and Prospects. In A. Nasim (ed) Financing Pakistan's Development in the 1990s. Karachi: Oxford University Press.

Moosa, I. A., and R. H. Bhatti (1996) Does Purchasing Power Parity Hold Between Japan and Other Asian Countries? Journal of International Economic Studies 10: 83-92.

Moosa, I. A., and R. H. Bhatti (1997) Are Asian Markets Integrated? Evidence from Six Asian Countries vis-à-vis Japan. International Economic Journal 11: 5167.

Moosa, I. A., and R. H. Bhatti (1997a) International Parity Conditions: Theory, Econometric Testing, and Empirical Evidence. London: Macmillan Press Ltd.

Nachane, D. M., and A. Chrissanthaki (1991) Purchasing Power Parity in the Short and Long Run: A Reappraisal of the Post-1973 Evidence. Applied Economics 23: $1257-1268$.

Patel, J. (1990) Purchasing Power Parity as a Long-run Relation. Journal of Applied Econometrics 5: 367-379.

Phillips, P. C. B., and S. Ouliaris (1990) Asymptotic Properties of Residual-based Tests for Cointegration. Econometrica 58: 165-193.

Pilbeam, K. (1992) International Finance. London: Macmillan Educational Ltd.

Roll, R. (1979) Violations of Purchasing Power Parity and Their Implications for Efficient International Commodity Markets. In M. Sarnat and G. P. Szego (eds) International Finance and Trade. Cambridge, Massachusetts: Ballinger.

Serletis, A. (1994) Maximum Likelihood Cointegration Tests of Purchasing Power Parity: Evidence from Seventeen OECD Countries. Weltwirtschafliches Archiv 130: 476-491.

Siddiqui, R., U. Afridi, and Z. Mahmood (1996) Exchange Rate Determination in Pakistan: A Simultaneous Equation Model. The Pakistan Development Review 35:4 682-690.

Stock, J. H. (1987) Asymptotic Properties of Least Square Estimates of Cointegrating Vectors. Econometrica 55: 1035-1056.

Taylor, M. P. (1988) An Empirical Examination of Long-run Purchasing Power Parity Using Cointegration Techniques. Applied Economics 20: 1369-1381.

West, K. D. (1988) Asymptotic Normality When Regressors Have a Unit Root. Econometrica 56: 1397-1418. 